UDK $577.1: 61$

ISSN 1452-8258

\title{
SIPA1 BOOSTS MIGRATION AND PROLIFERATION, AND BLOCKS APOPTOSIS OF GLIOMA BY ACTIVATING THE PHOSPHORYLATION OF THE FAK SIGNALING PATHWAY
}

\author{
SIPA1 POSPEŠUJE MIGRACIJU I PROFILACIJU, I BLOKIRA APOPTOZU GLIOME \\ AKTIVIRANJEM FOSFORILACIJE SIGNALINOG PUTA FOKALNE ADHEZIONE KINAZE \\ Yuan $\mathrm{Du}^{1,2}$, Shenglan $\mathrm{Li}^{3}$, Tong Zhou ${ }^{4}$, Jing Zhao ${ }^{5}$, Jiguang $\mathrm{Liu}^{6}$ \\ ${ }^{1}$ School of Basic Medicine Science, Jiamusi University, Jiamusi, China \\ ${ }^{2}$ The Central Hospital of Jamusi City, Jiamusi, China \\ ${ }^{3}$ Department of Neuro-oncology, Cancer center, Beijing Tiantan Hospital, Capital Medical University, Beijing, China \\ ${ }^{4}$ School of Pharmacy, Jiamusi University, Jiamusi, China \\ ${ }^{5}$ Clinical Laboratory, the First Affiliated Hospital of Jiamusi University, Jiamusi, China \\ ${ }^{6}$ School of Stomatology, Jiamusi University, Jiamusi, China
}

\section{Summary}

Background: We aimed to analyze the regulatory effects of SIPA1 (signal-induced proliferation-associated protein 1) on glioma progression and the dominant signaling pathway.

Methods: Differential level of SIPA1 in glioma and normal tissues and cells was determined. Migratory, proliferative, apoptotic and cell cycle progression changes in A172 cells with overexpression or knockdown of SIPA1 were examined. Finally, protein levels of phosphorylated FAKs in A172 cells intervened by SIPA1, and the FAK inhibitor PF562271 were detected.

Results: SIPA1 was upregulated in glioma cases. Knockdown of SIPA1 reduced migratory and proliferative rates of glioma cells, increased apoptotic cell rate, and declined cell ratio in the S phase. The knockdown of SIPA1 also downregulated cell cycle proteins. In addition, SIPA1 upregulated phosphorylated FAKs in A172 cells and thus boosted malignant phenotypes of glioma.

Conclusions: SIPA1 is upregulated in glioma that boosts migratory and proliferative potentials of glioma cells by activating the phosphorylation of the FAK signaling pathway.

Keywords: SIPA1, FAK, phosphorylation, glioma

\section{Kratak sadržaj}

Uvod: Cilj nam je bio da analiziramo regulatorne efekte SIPA1 na progresiju glioma i dominantni signalni put.

Metode: Određen je diferencijalni nivo SIPA1 u gliomu i normalnim tkivima i ćelijama. Ispitivane su migratorne, proliferativne, apoptotičke i promene u progresiji ćelijskog ciklusa u ćelijama A172 sa prekomernom ekspresijom ili obaranjem SIPA1. Konačno, otkriveni su nivoi proteina fosforilisanih FAK u ćelijama A172 sa intervencijom SIPA1 i inhibitorom FAK PF-562271.

Rezultati: SIPA1 je uvećan u slučajevima glioma. Pad SIPA1 je smanjio migracijsku i proliferativnu stopu ćelija glioma, povećao apoptotičku ćelijsku stopu i smanjio ćelijski odnos u S fazi. Snižavanjem SIPA1 takođe su sniženi i proteini ćelijskog ciklusa. SIPA1 je povećao fosforilisani FAK u ćelijama A172 i tako pojačao maligne fenotipe glioma.

Zaključak: SIPA1 je povećan kod glioma i pojačava migratorne i proliferativne potencijale ćelija glioma aktiviranjem fosforilacije signalnog puta FAK.

Ključne reči: SIPA1, FAK, fosforilacija, gliom

Address for correspondence:

Jiguang Liu, MD

School of Stomatology, Jiamusi University, 522 Hongqi Street,

Jiamusi, Heilongjiang 154000, China

Phone: 86013694668555

e-mail: 13694668555@163.com 


\section{Introduction}

Gliomas are the leading malignant tumors of the central nervous system that originate from glial cells of the neuroectoderm. They represent $80 \%$ of primary intracranial malignancies (1). The average survival time of glioma is only 12-14 months (2). Currently, surgery combined radiotherapy, chemotherapy and biotherapy is preferred to glioma patients, although they can only prolong the survival for months. The prognosis of glioma is extremely poor (3). Clarification of the pathogenesis of glioma and the involvement of differentially expressed genes in glioma contributes to the improvement of clinical outcomes (4).

SIPA1 (signal-induced proliferation-associated protein 1) is a protein relevant to tumor invasiveness and metastasis. It is located on human chromosome $11 \mathrm{q} 13.3$, containing a zinc finger at the $C$ terminal and a GTPase activator that is highly homologic with Rap1GAP at the $\mathrm{N}$ terminal $(5,6)$. RapGAP protein constitutes Rap1GAP and SIPA1 (7). As a specific RapGAP protein, SIPA1 negatively regulates Rap1 by converting it to the inactivate GDP-bound state, thus translocating signals into nuclei that mediates gene transcription (8). Rap1 is highly homologic with Ras, sharing similar functions in regulating cell-cell connection, secretion, and adhesion (9). In addition, SIPA1 also participates in the mediation of cell clonality, adhesion, and migration (10). This study aims to explore the regulatory effects of SIPA1 on glioma and the dominant signaling pathway.

\section{Materials and Methods}

\section{Collection of glioma samples}

Glioma samples $(n=32)$ were surgically resected and collected. Glioma cases were pathologically confirmed, and they did not have preoperative glioma treatments. Normal brain tissue samples $(n=24)$ resected during craniocerebral decompression in patients with brain traumas were collected as controls. The Ethic Committee of The Central Hospital of Jamusi City approved this study, and written informed consent was obtained from each patient.

\section{Cell culture}

The GBM-derived T98G and A172 cell lines, the grade III astrocytoma-derived U87 cell line and astrocyte cell line NHA (American Type Culture Collection (ATCC) (Manassas, VA, USA)) were cultivated in Dulbecco's Modified Eagle Medium (DMEM) (Gibco, Rockville, MD, USA) supplemented with 10\% fetal bovine serum (FBS) (Gibco, Rockville, MD, USA) in an incubator containing $5 \% \mathrm{CO}_{2}$ at $37^{\circ} \mathrm{C}$. Cell passage was conducted at $80 \%$ of confluence.

\section{Cell transfection}

Cells seeded in a 6-well plate were grown to $80 \%$ of confluence, followed by the transfection of vectors constructed by GenePharma (Shanghai, China) using Lipofectamine 2000 (Invitrogen, Carlsbad, CA, USA). Transfection efficacy was examined by quantitative real-time polymerase chain reaction (qRT-PCR) at $24 \mathrm{~h}$.

\section{qRT-PCR}

Cells were lysed in TRIzol (Invitrogen, Carlsbad, CA, USA) for $5 \mathrm{~min}$, followed by incubation in $200 \mu \mathrm{L}$ of chloroform. After $12,000 \times \mathrm{g}$ centrifugation at $4{ }^{\circ} \mathrm{C}$ for $5 \mathrm{~min}$, the upper layer was collected and incubated with $500 \mu \mathrm{L}$ of isopropanol. After $12,000 \times \mathrm{g}$ centrifugation at $4{ }^{\circ} \mathrm{C}$ for $10 \mathrm{~min}$, the precipitant was washed in $1 \mathrm{~mL}$ of $75 \%$ ethanol and diluted in $20 \mu \mathrm{L}$ of diethylpyrocarbonate (DEPC) water (Beyotime, Shanghai, China). RNA concentration was measured using NanoDrop 2000 (Thermo Fisher Scientific, Inc., Waltham, MA, USA). Using the PrimeScript ${ }^{\text {TM }}$ RT Master Mix, reversely transcribed complementary deoxyribose nucleic acids (cDNAs) were further subjected to $\mathrm{qPCR}$.

SIPA1-Forward: 5'-TGCAAGATGGTGGCAGTCCTC-3'; SIPA1-Reverse: 5'-CTGCCCGCCTCCGACATGATC-3'; GAPDH-Forward: 5'-ACACCATGGGGAAGGTGAAG-3'; GAPDH-Reverse: 5'-GTGACCAGGCGCCCAATA-3'; Cyclin A2-Forward: 5'-CGCTGGCGGTACTGAAGTC-3'; Cyclin A2-Reverse: 5'-GAGGAACGGTGACATGCTCAT-3'; Cyclin D1-Forward: 5'-GCTGCGAAGTGGAAACCATC-3'; Cyclin D1-Reverse: 5'-CCTCCTTCTGCACACATTTGAA-3'; Cyclin E1Forward: 5'-AAGGAGCGGGACACCATGA-3'; Cyclin E1-Reverse: 5'-ACGGTCACGTTTGCCTTCC-3'.

\section{Transwell}

Cell suspension $\left(5 \times 10^{4} / \mathrm{L}\right)$ in serum-free medium and medium containing 10\% FBS were respectively applied at the top and bottom of a Transwell insert pre-coated with $200 \mathrm{mg} / \mathrm{mL}$ Matrigel. After 24$\mathrm{h}$ cell culture, cells migrated from the top to the bottom were fixed in $70 \%$ ethanol for $30 \mathrm{~min}$ and dyed in $0.2 \%$ crystal violet for $10 \mathrm{~min}$, which were then observed and counted.

\section{5-Ethynyl-2'- deoxyuridine (EdU)}

Cell suspension $\left(2 \times 10^{5} / \mathrm{L}\right)$ was seeded in a 96 well plate and stained with EdU as recommended by the commercial kit (Beyotime, Shanghai, China). EdU-positive cells in 3 random fields per well were captured for calculating using Image J software $(\mathrm{NIH}$, Bethesda, MD, USA). 


\section{Flow cytometry}

After 5-min centrifugation at 1,000 r/min and phosphate-buffered saline (PBS) washing twice, the precipitant was induced with $5 \mu \mathrm{L}$ of Annexin V/FITC and $10 \mu \mathrm{L}$ of Propidium lodide (PI) in the dark for 15 min. Cell apoptosis was analyzed by detecting FL1 (488 nm wavelength) and FL2 gate (633 nm wavelength). In addition, cell cycle distribution was analyzed using the CellQuestTMD Analysis Software (BD Biosciences, Franklin Lakes, NJ, USA).

\section{Western blot}

After 30-min lysis of cells, and 15-min centrifugation at $4{ }^{\circ} \mathrm{C}, 12,000 \mathrm{rpm}$, protein samples were prepared for sodium dodecyl sulphate-polyacrylamide gel electrophoresis (SDS-PAGE) (30 $\mathrm{g}$ per lane) and transfer on polyvinylidene fluoride (PVDF) membranes (Millipore, Billerica, MA, USA). After blocking non-specific antigens on membranes, they were induced with primary and secondary antibodies under indicated conditions. Protein signals were detected using Luminol substrate solution.

\section{Statistical analysis}

Statistical Product and Service Solutions (SPSS) 22.0 (IBM, Armonk, NY, USA) was used for statistical processing. Data were expressed as $\bar{X} \pm s$, and differences between groups were compared using the independent t-test. A significant difference was set at $\mathrm{P}<0.05$.

\section{Results}

\section{Upregulation of SIPA1 in glioma}

Compared with normal brain tissues, mRNA and protein levels of SIPA1 were remarkably upregulated in glioma (Figure 1A, 1B). Meanwhile, SIPA1 was more highly expressed in glioma cell lines than astrocytes (Figure 1C, 1D). A172 cells were used for the following experiments since they expressed a relatively high abundance of SIPA1 in the three tested glioma cell lines.

Knockdown of SIPA 1 suppressed migratory and proliferative potentials of glioma

SIPA1 level was effectively suppressed by transfection of si-SIPA1 in A172 cells (Figure 2A). After the knockdown of SIPA1, the migratory cell number (Figure 2B) and EdU-positive ratio (Figure 2C) were markedly reduced. In addition, cell apoptosis was stimulated by transfection of si-SIPA1 (Figure 2D). Flow cytometry data showed that the knockdown of SIPA1 in A172 cells arrested cell cycle progression in the $\mathrm{G} 1$ phase, which was further supported by the downregulation of cell cycle proteins Cyclin A2, Cyclin D1 and Cyclin E1 in glioma cells with SIPA1 knockdown (Figure 2E, 2F).

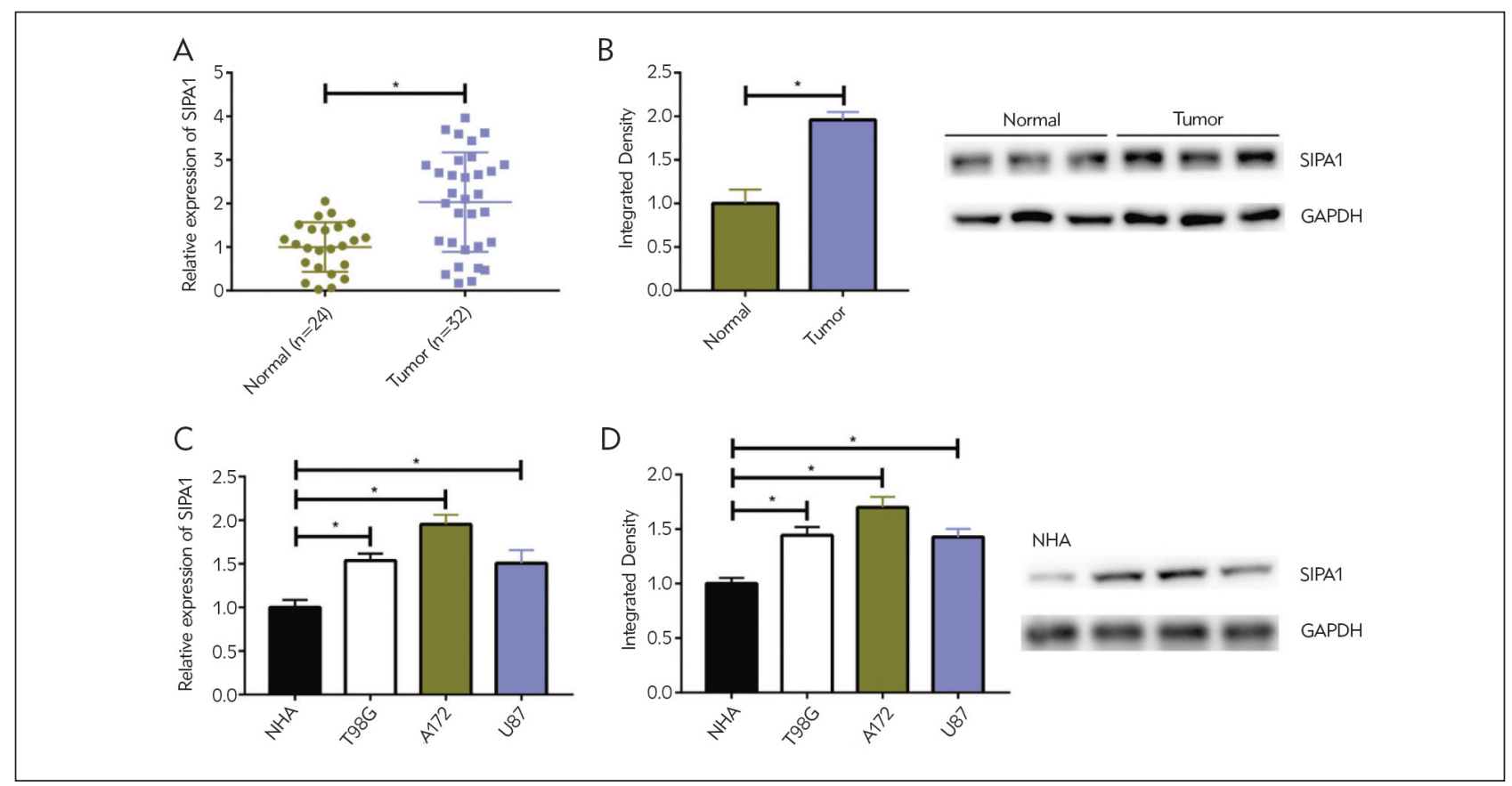

Figure 1 Upregulation of SIPA1 in glioma. (A) The mRNA level of SIPA1 in glioma and normal brain tissues; (B) The protein level of SIPA1 in glioma and normal brain tissues; (C) The mRNA level of SIPA1 in glioma cell lines; (D) The protein level of SIPA1 in glioma cell lines; ${ }^{*} \mathrm{P}<0.05$. 
A

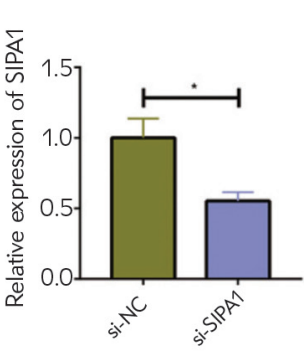

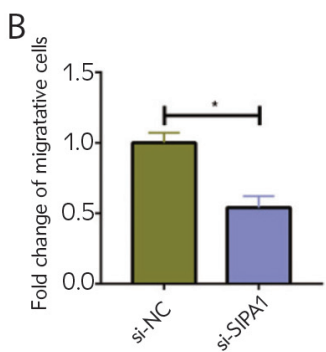

C
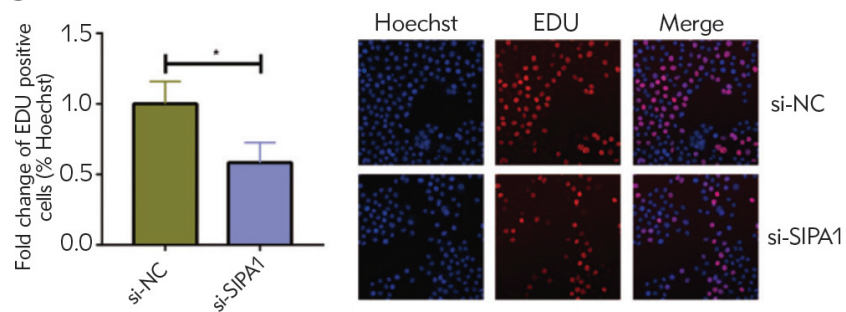

D

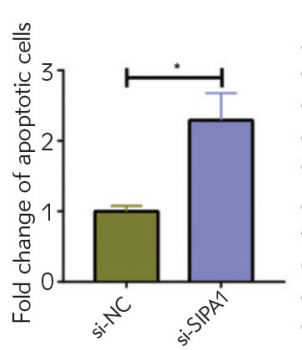

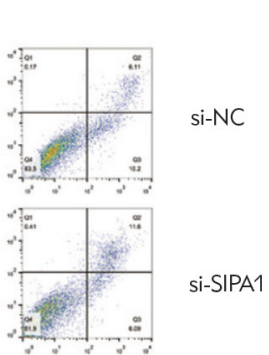
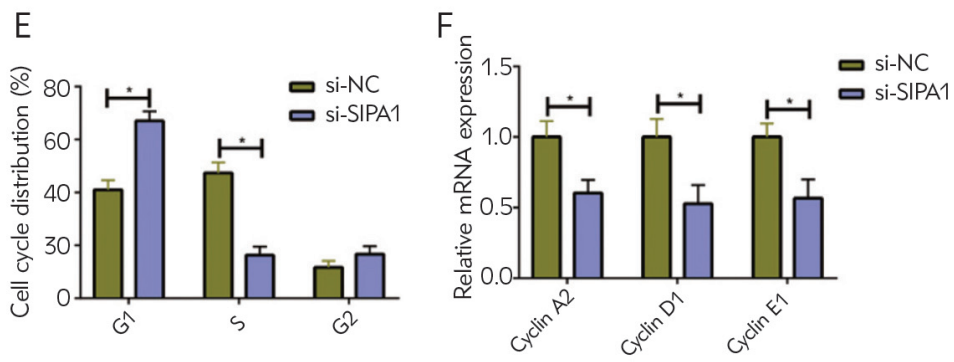

Figure 2 Knockdown of SIPA1 suppressed migratory and proliferative potentials of glioma. (A) Transfection efficacy of si-SIPA1 in A172 cells; (B) Migration in A172 cells with SIPA1 knockdown; (C) EdU-positive ratio in A172 cells with SIPA1 knockdown (magnification $=40 \times$ ); (D) Apoptosis in A172 cells with SIPA1 knockdown; (E) Cell cycle distribution in A172 cells with SIPA1 knockdown; (F) Relative levels of Cyclin A2, Cyclin D1 and Cyclin E1 in A172 cells with SIPA1 knockdown; ${ }^{*}$ P $<0.05$.

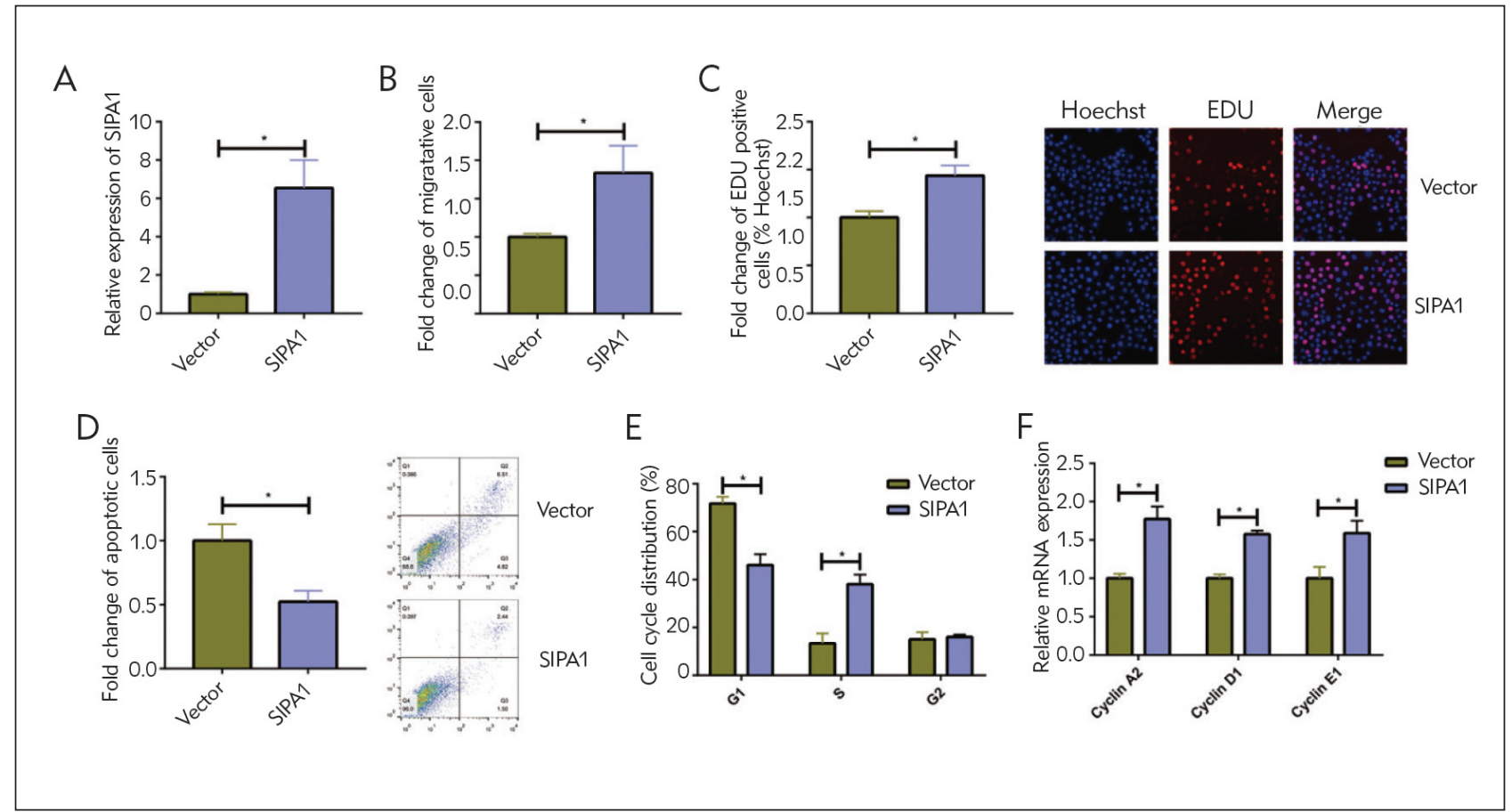

Figure 3 Overexpression of SIPA1 suppressed migratory and proliferative potentials of glioma. (A) Transfection efficacy of SIPA1 overexpression vector in A172 cells; (B) Migration in A172 cells with SIPA1 overexpression; (C) EdU-positive ratio in A172 cells with SIPA1 overexpression (magnification $=40 \times$ ); (D) Apoptosis in A172 cells with SIPA1 overexpression; (E) Cell cycle distribution in A172 cells with SIPA1 overexpression; (F) Relative levels of Cyclin A2, Cyclin D1 and Cyclin E1 in A172 cells with SIPA1 overexpression; ${ }^{*} \mathrm{P}<0.05$. 


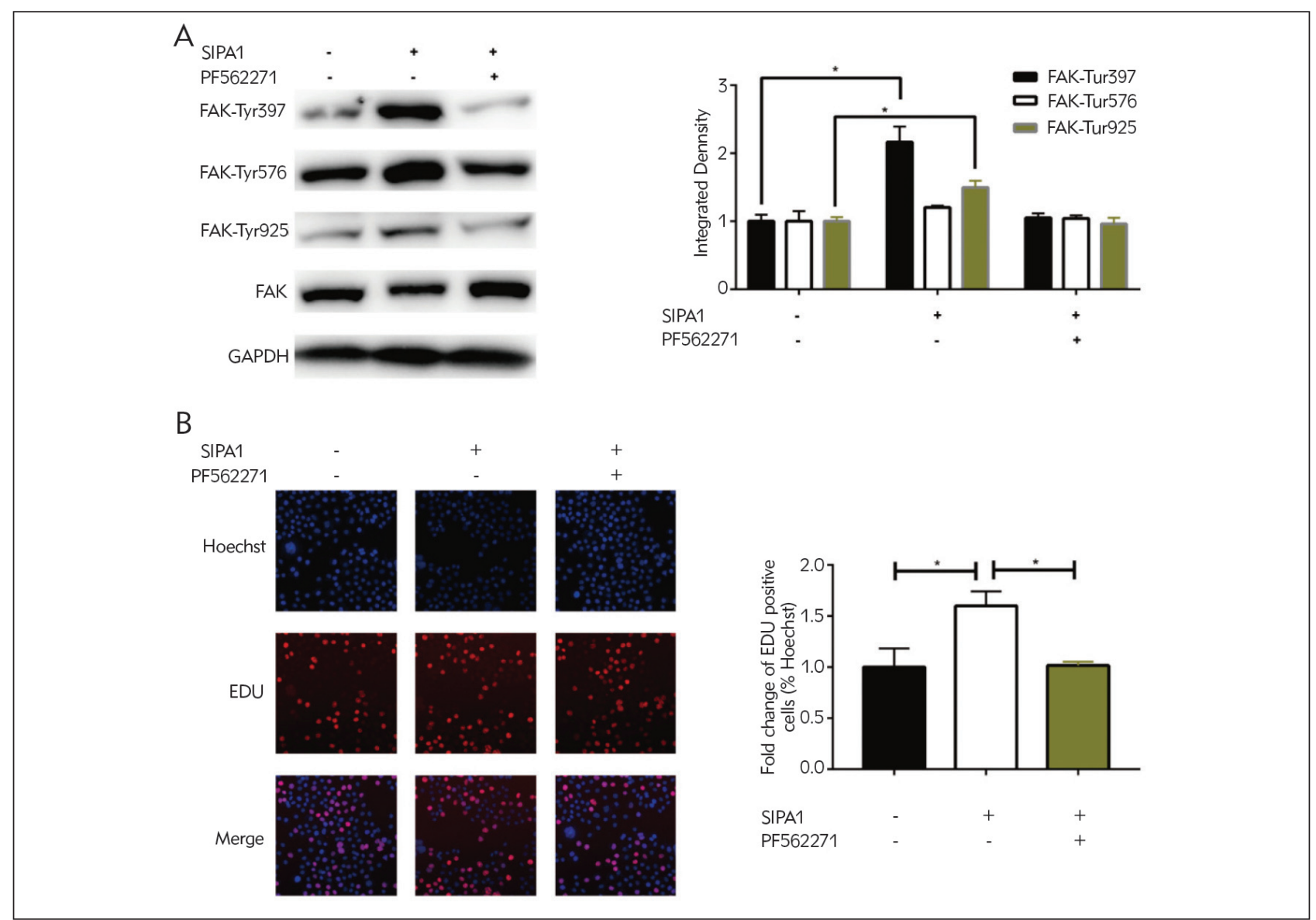

Figure 4 Overexpression of SIPA1 activated phosphorylation of FAK. A172 cells were transfected with negative control or SIPA1 overexpression vector, followed by either treatment of PF-562271 or not; (A) Protein levels of Phospho-FAK (Try397), PhosphoFAK (Try576), Phospho-FAK (Try925) and FAK; (B) EdU-positive ratio in A172 cells (magnification $=40 \times$ ); ${ }^{*} \mathrm{P}<0.05$.

Overexpression of SIPA 1 boosted migratory and proliferative potentials of glioma

We analyzed phenotype changes of A172 cells overexpressing SIPA1 further (Figure 3A). Overexpression of SIPA1 markedly enhanced migratory and proliferative potentials of glioma cells (Figure 3B, $3 C$ ). In addition, the apoptosis rate was reduced in A172 cells overexpressing SIPA1 (Figure 3D). Besides, overexpression of SIPA1 remarkably prolonged the S phase and upregulated Cyclin A2, Cyclin D1 and Cyclin E1 (Figure 3E, 3F).

Overexpression of SIPA1 activated phosphorylation of FAK

Interestingly, overexpression of SIPA1 in A172 cells upregulated Phospho-FAK (Try397), PhosphoFAK (Try576) and Phospho-FAK (Try925), which were reversed by treatment of the FAK inhibitor PF562271 (Figure 4A). To further explore the involvement of the phosphorylated FAK in SIPA1-induced glioma progression, proliferative ability in glioma cells overexpressing SIPA1 intervened by PF-562271 was examined. As expected, the intervention of PF562271 reduced the EdU-positive rate, indicating that the phosphorylation of FAK did participate in glioma progression boosted by SIPA1 (Figure 4B).

\section{Discussion}

Glioma is a complicated malignant tumor. Its pathogenesis remains largely unclear, and brain traumas, nitrite food, occupational hazard and radiation exposure may be potential risk factors of glioma. Besides, immune factors are closely associated with the development of glioma, involving Treg, $\mathrm{CD}^{+} \mathrm{T}$, $\mathrm{CD} 4^{+} \mathrm{T}$ and $\mathrm{CD} 8^{+} \mathrm{T}$ cells (11). Therefore, differentially expressed genes in gliomas have been well concerned. They can be utilized as specific biomarkers for guiding the screening, diagnosis and treatment, and predicting the prognosis of glioma (12). The development of targeted therapy based on these biomarkers is a promising approach to improving glioma patients' poor prognosis $(13,14)$.

The cancer-associated role of SIPA1 differs in human malignant tumors. Hunter et al. (15) first 
identified that SIPA1 is located on the metastasis efficiency modifier locus mtes1. SIPA1 SNP remarkably influences the function of Rap GTPase. They demonstrated that intervention of SIPA1 in nude mice markedly alters the metastatic ability of cancer cells. Minato et al. (16) suggested that SIPA1 prevents cell adhesion to fibronectin by inhibiting Rap1GTP in Hela cells. Through mediating the interaction between SIPA1 and Rap1GTP, AF-6 inhibits integrininduced cell adhesion (17). The diasporin pathway can regulate transcription of extracellular matrix (ECM) genes, pTEN and Trp53, which is a tumor progression-associated pathway regulated by SIPA1 (18, 19). In hematological malignancies, SIPA1 acts as a tumor-suppressor gene. SIPA1 knockout mice showed $\mathrm{T}$ cell non-responsiveness before bone marrow dysfunction, which eventually leads to the development of delayed myeloid leukemia (20). SIPA1 is distributed in nuclei of breast cancer cell line MDAMB-231. By promoting the expression of integrin 1 by acting on its promoter, SIPA1 further activates the phosphorylation of FAK, and thus regulates invasiveness and morphology of breast cancer cells through the MMP9 signaling and F-actin, respectively (21). In vivo overexpression of SIPA1 enhances tumorigenesis of prostate cancer in SCID mice by inhibiting the binding between collagen and fibronectin, thus inactivating ECM-induced activation of Rap1. Meanwhile, overexpression of SIPA1 downregulates Brd4, which further attenuates the binding between prostate cancer cells and ECM (22). The regulatory effect of SIPA1 on the migratory capacity of colorectal carcino$\mathrm{ma}(\mathrm{CRC})$ is quite the opposite of that in breast cancer and prostate cancer. A clinical trial involving 94 CRC patients revealed that the relative level of SIPA1 is negatively correlated to metastatic lymphatic rate. Knockdown of SIPA1 markedly triggers the migratory ability of CRC cells (23). In the present study, SIPA1 was highly expressed in glioma cases, which boosted migratory and proliferative capacities of glioma cells and inhibited cell apoptosis.

\section{References}

1. Patil N, Kelly ME, Yeboa DN, Buerki RA, Cioffi G, Balaji $\mathrm{S}$, et al. Epidemiology of brainstem high-grade gliomas in children and adolescents in the United States, 20002017. Neuro Oncol 2021; 23: 990-8.

2. Stetson LC, Dazard JE, Barnholtz-Sloan JS. Protein Markers Predict Survival in Glioma Patients. Mol Cell Proteomics 2016; 15: 2356-65.

3. Ryskalin L, Biagioni F, Lenzi P, Frati A, Fornai F. mTOR Modulates Intercellular Signals for Enlargement and Infiltration in Glioblastoma Multiforme. Cancers (Basel) 2020; 12: 2486.

4. Kunadis E, Lakiotaki E, Korkolopoulou P, Piperi C. Targeting post-translational histone modifying enzymes in glioblastoma. Pharmacol Ther 2020: 107721.
FAK is overactivated or over-phosphorylated in multiple types of cancer cells, leading to malignant migration, proliferation, adhesion and EMT (24). In addition to the kinase function, FAK also serves as a scaffold for protein complexes that regulates cancer development (25). Here, overexpression of SIPA1 upregulated Phospho-FAK (Try397), Phospho-FAK (Try576) and Phospho-FAK (Try925), which were reversed by treatment of the FAK inhibitor PF562271. The treatment of PF-56271 abolished the boosted proliferative ability of glioma by overexpression of SIPA1. It is indicated that the phosphorylation of FAK was involved in the glioma progression boosted by SIPA1.

There were limitations in the present study. First of all, the sample size of glioma and normal brain tissues was limited. Therefore, the clinical significance of SIPA1 in glioma needs to be further validated in more samples. Secondly, in vivo experiments are Ineeded to verify the tumorigenic role of SIPA1 in glioma.

\section{Conclusion}

SIPA1 is upregulated in glioma, which boosts malignant progression of glioma by activating the phosphorylation of the FAK signaling pathway.

\section{Financial Disclosure}

The authors declared that this study had received no financial support.

\section{Conflict of interest statement}

All the authors declare that they have no conflict of interest in this work.
5. Kurachi $\mathrm{H}$, Wada $\mathrm{Y}$, Tsukamoto $\mathrm{N}$, Maeda M, Kubota $\mathrm{H}$, Hattori $M$, et al. Human SPA-1 gene product selectively expressed in lymphoid tissues is a specific GTPase-activating protein for Rap1 and Rap2. Segregate expression profiles from a rap1GAP gene product. J Biol Chem 1997; 272: 28081-8.

6. Rubinfeld B, Crosier WJ, Albert I, Conroy L, Clark R, McCormick F, et al. Localization of the rap1GAP catalytic domain and sites of phosphorylation by mutational analysis. Mol Cell Biol 1992; 12: 4634-42.

7. Minato N. Rap G protein signal in normal and disordered lymphohematopoiesis. Exp Cell Res 2013; 319: 2323-8.

8. Ohba Y, Ikuta K, Ogura A, Matsuda J, Mochizuki N, Nagashima K, et al. Requirement for C3G-dependent 
Rap1 activation for cell adhesion and embryogenesis. Embo J 2001; 20: 3333-41.

9. Lee MR, Jeon TJ. Cell migration: regulation of cytoskeleton by Rap1 in Dictyostelium discoideum. J Microbiol 2012; 50: 555-61.

10. Raaijmakers JH, Bos JL. Specificity in Ras and Rap signaling. J Biol Chem 2009; 284: 10995-9.

11. Dolecek TA, Propp JM, Stroup NE, Kruchko C. CBTRUS statistical report: primary brain and central nervous system tumors diagnosed in the United States in 20052009. Neuro Oncol 2012; 14 Suppl 5: v1-49.

12. Diamandis $P$, Aldape KD. Insights From Molecular Profiling of Adult Glioma. J Clin Oncol 2017; 35: 238693.

13. Chekhonin IV, Chistiakov DA, Grinenko NF, Gurina OI. Glioma Cell and Astrocyte Co-cultures As a Model to Study Tumor-Tissue Interactions: A Review of Methods. Cell Mol Neurobiol 2018; 38: 1179-95.

14. Freret ME, Gutmann DH. Insights into optic pathway glioma vision loss from mouse models of neurofibromatosis type 1. J Neurosci Res 2019; 97: 45-56.

15. Park YG, Zhao X, Lesueur F, Lowy DR, Lancaster $M$, Pharoah $\mathrm{P}$, et al. Sipa1 is a candidate for underlying the metastasis efficiency modifier locus Mtes1. Nat Genet 2005; 37: 1055-62.

16. Tsukamoto N, Hattori M, Yang H, Bos JL, Minato N. Rap1 GTPase-activating protein SPA-1 negatively regulates cell adhesion. J Biol Chem 1999; 274: 18463-9.

17. Su L, Hattori M, Moriyama M, Murata N, Harazaki M, Kaibuchi $K$, et al. AF- 6 controls integrin-mediated cell adhesion by regulating Rap1 activation through the specific recruitment of Rap1GTP and SPA-1. J Biol Chem 2003; 278: 15232-8.
18. Crawford NP, Walker RC, Lukes L, Officewala JS, Williams RW, Hunter KW. The Diasporin Pathway: a tumor progression-related transcriptional network that predicts breast cancer survival. Clin Exp Metastasis 2008; 25: 357-69.

19. Farina A, Hattori M, Qin J, Nakatani Y, Minato N, Ozato $\mathrm{K}$. Bromodomain protein Brd4 binds to GTPase-activating SPA-1, modulating its activity and subcellular localization. Mol Cell Biol 2004; 24: 9059-69.

20. Ishida D, Kometani K, Yang H, Kakugawa K, Masuda K, Iwai K, et al. Myeloproliferative stem cell disorders by deregulated Rap1 activation in SPA-1-deficient mice. Cancer Cell 2003; 4: 55-65.

21. Zhang $Y$, Gong $Y$, Hu D, Zhu P, Wang N, Zhang $Q$, et al. Nuclear SIPA1 activates integrin beta1 promoter and promotes invasion of breast cancer cells. Oncogene 2015; 34: 1451-62.

22. Shimizu Y, Hamazaki Y, Hattori M, Doi K, Terada N, Kobayashi $\mathrm{T}$, et al. SPA-1 controls the invasion and metastasis of human prostate cancer. Cancer Sci 2011; 102: 828-36.

23. Ji K, Ye L, Toms AM, Hargest R, Martin TA, Ruge F, et al. Expression of signal-induced proliferation-associated gene 1 (SIPA1), a RapGTPase-activating protein, is increased in colorectal cancer and has diverse effects on functions of colorectal cancer cells. Cancer Genomics Proteomics 2012; 9: 321-7.

24. Zhang J, Hochwald SN. The role of FAK in tumor metabolism and therapy. Pharmacol Ther 2014; 142: 154-63.

25. Cance WG, Kurenova E, Marlowe T, Golubovskaya V. Disrupting the scaffold to improve focal adhesion kinasetargeted cancer therapeutics. Sci Signal 2013; 6: e10. 